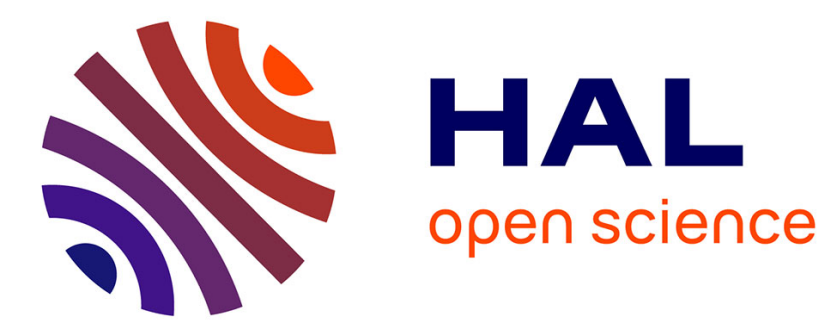

\title{
Monitoring energy and mass transfers during the Alpilles-ReSeDA experiment
}

A Olioso, Isabelle Braud, A Chanzy, M Demarty, Y Ducros, Jc Gaudu, E Gonzalez-Sosa, E Lewan, O Marloie, C Ottle, et al.

\section{- To cite this version:}

A Olioso, Isabelle Braud, A Chanzy, M Demarty, Y Ducros, et al.. Monitoring energy and mass transfers during the Alpilles-ReSeDA experiment. Agronomie, 2002, 22 (6), pp.597-610. 10.1051/agro:2002051 . hal-01863542

\section{HAL Id: hal-01863542 \\ https://hal.science/hal-01863542}

Submitted on 1 Jun 2020

HAL is a multi-disciplinary open access archive for the deposit and dissemination of scientific research documents, whether they are published or not. The documents may come from teaching and research institutions in France or abroad, or from public or private research centers.
L'archive ouverte pluridisciplinaire HAL, est destinée au dépôt et à la diffusion de documents scientifiques de niveau recherche, publiés ou non, émanant des établissements d'enseignement et de recherche français ou étrangers, des laboratoires publics ou privés. 


\title{
Original article
}

\section{Monitoring energy and mass transfers during the Alpilles-ReSeDA experiment*}

\author{
Albert OLIOSO $^{\mathrm{a} * *}$, Isabelle BRAUD ${ }^{\mathrm{b}, \mathrm{n}}$, André CHANZY ${ }^{\mathrm{a}}$, Jérome DEMARTY, ${ }^{\mathrm{c}, \mathrm{a}}$, Yannick DUCROS ${ }^{\mathrm{a}}$, \\ Jean-Claude GAUdu ${ }^{a}$, Enrique GONZALEZ-SOSA ${ }^{\mathrm{b}}$, Elizabet LEWAN ${ }^{\mathrm{e}}$, Olivier MARLOIE ${ }^{\mathrm{a}}$, Catherine OTTLÉc, \\ Laurent PRÉVOT ${ }^{\mathrm{a}}$, Jean-Louis THONY ${ }^{\mathrm{b}}$, Hervé AUTRET ${ }^{\mathrm{f}}$, Olivier BETHENOD ${ }^{\mathrm{f}}$, Jean-Marc BONNEFOND ${ }^{\mathrm{g}}$, \\ Nadine BRUGUIER ${ }^{\mathrm{a}}$, Jean-Paul BUIS ${ }^{\mathrm{h}}$, Jean-Christophe CALVET ${ }^{\mathrm{i}}$, Vicente CASELLES ${ }^{\mathrm{j}}$, Habiba CHAUKI ${ }^{\mathrm{a}}$, \\ Cesar COLL ${ }^{\mathrm{j}}$, Christophe FRANÇOIS ${ }^{\mathrm{c}, \mathrm{o}}$, Robert GOUJET ${ }^{\mathrm{f}}$, Raymond JONGSCHAAP ${ }^{\mathrm{k}}$, Yann KERR ${ }^{\mathrm{d}}$, Christine KING , $^{1}$ \\ Jean-Pierre LAGOUARDE ${ }^{\mathrm{g}}$, Jean-Paul LAURENT ${ }^{\mathrm{b}}$, Patrice LECHARPENTIER ${ }^{\mathrm{a}}$, John MCANENEY ${ }^{\mathrm{m}}$, \\ Sophie MOULIN ${ }^{\text {,a }}$, Eva RUBIO ${ }^{\mathrm{j}}$, Marie WEISS ${ }^{\mathrm{a}}$, Jean-Pierre WIGNERON ${ }^{\mathrm{a}, \mathrm{g}}$ \\ ${ }^{a}$ INRA Climat, Sol et Environnement, Site Agroparc, Domaine St-Paul, 84914 Avignon Cedex 9, France \\ ${ }^{\mathrm{b}}$ LTHE (UMR 5564 CNRS, INPG, IRD, UJF), Grenoble, France \\ ${ }^{\mathrm{c}}$ CETP, Vélizy, France \\ ${ }^{\mathrm{d}}$ CESBIO, Toulouse, France \\ ${ }^{\mathrm{e}}$ University of Agricultural Sciences, Uppsala, Sweden \\ ${ }^{\mathrm{f}}$ INRA Bioclimatologie, Grignon, France \\ g INRA Bioclimatologie, Villenave d'Ornon, France \\ ${ }^{\mathrm{h}}$ CIMEL Électronique, Paris, France \\ ${ }^{\mathrm{i}}$ CNRM, Toulouse, France \\ ${ }^{\mathrm{j}}$ University of Valencia, Spain \\ ${ }^{\mathrm{k}}$ Plant Research International Ltd., Wageningen, The Netherlands \\ ${ }^{1}$ BRGM, Orléans, France \\ ${ }^{m}$ Strategic Decisions Group, Auckland, New Zealand \\ ${ }^{n}$ CEMAGREF, Lyon, France \\ ${ }^{\circ}$ Université Paris-Sud, Orsay, France
}

(Received 30 October 2001; accepted 18 June 2002)

\begin{abstract}
The Alpilles-ReSeDA program was initiated to develop and test methods for interpreting remote sensing data that could lead to a better evaluation of soil and vegetation processes. This article presents the experiment that was setup in order to acquire the necessary data to achieve this goal. Intensive measurements were performed for almost one year over a small agricultural region in the South of France (20 kilometers square). To capture the main processes controlling land-atmosphere exchanges, the local climate was fully characterized, and surface energy fluxes, vegetation biomass, vegetation structure, soil moisture profiles, surface soil moisture, surface temperature and soil temperature were monitored. Additional plant physiological measurements and a full characterization of physical soil parameters were also carried out. After presenting the different types of measurements, examples are given in order to illustrate the variability of soils and plant processes in the area in response to the experienced climate.
\end{abstract}

surface energy fluxes / evapotranspiration / soil moisture / soil physical properties / experiment / vegetation characterization

Résumé - Suivi des échanges d'énergie et de masse au cours de l'expérimentation Alpilles-ReSeDA. Le programme Alpilles-ReSeDA a été mis en place pour développer et tester des méthodes permettant une meilleure utilisation des données de télédétection pour le suivi du fonctionnement des sols et des cultures. Cet article présente l'expérimentation qui a été réalisée pour acquérir un jeu de données permettant cette analyse. Des mesures intensives ont été réalisées pendant presque une année sur une petite région agricole du Sud de la France (20 kilomètres carrés). De façon à suivre l'ensemble des processus contrôlant les échanges surface-atmosphère, l'ensemble des paramètres climatiques locaux ont été mesurés, ainsi que les flux d'énergie de surface, les caractéristiques de structure de la végétation et du sol, l'humidité et les températures du sol, la température de surface. Des mesures des paramètres physiologiques des plantes et des caractéristiques physiques des sols ont également été entreprises. Après avoir présenté les différents types de mesures réalisées, des exemples présentant la variabilité des couverts végétaux et des sols dans la zone d'étude sont présentés.

flux d'énergie de surface / évapotranspiration / propriétés physiques des sols / expérimentation / caractérisation de la végétation

Communicated by Frédéric Baret (Avignon, France)

* This paper is dedicated to Jean-Louis Thony.

** Correspondence and reprints

olioso@avignon.inra.fr 


\section{INTRODUCTION}

The Alpilles-ReSeDA program was initiated to develop and test methods for interpreting remote sensing data that could lead to a better evaluation of soil and vegetation functioning (biomass production, crop yield, energy balance and water budget). ReSeDA stands for Remote Sensing Data Assimilation (the full name being: Assimilation of multisensor and multitemporal remote sensing data to monitor soil and vegetation functioning). The proposed approach is based on the assimilation of remote sensing data into soil and vegetation functioning models (Olioso et al. [27] and Prévot et al. [33]).

Among these models, Soil-Vegetation-Atmosphere Transfer models (SVAT models) have been developed to describe our current understanding of the physical and biophysical processes that occur between the atmosphere, vegetation and soil. They describe the physical processes that control energy and mass transfers in the soil-vegetation-atmosphere continuum (radiative, turbulent and water transfers) and provide estimates of the time course of soil and vegetation state variables with a fine time step compatible with the dynamics of atmospheric processes. They have been mainly used for energy and water balance assessments in meteorological, climatological and hydrological studies. They may also be used to estimate the surface temperature that can be measured in the thermal infrared domain, and for some of them, the surface soil moisture that might be measured in the microwave domain. They have been proposed for monitoring energy balance or soil moisture by using remote sensing data by means of assimilation procedures [5-7, 28, 31, 37, 38, 41]. Some authors have also proposed forcing vegetation characteristics estimated from reflectance measurements into SVAT models $[25,31,36]$.

In the framework of the Alpilles-ReSeDA program, a large experiment was set up to characterize transfer of energy and water between the soil, the vegetation and the atmosphere on the scale of a small agricultural region over one year. This experiment included a large range of remote sensing measurements from satellite or airborne sensors, as well as a large number of ground measurements of meteorological, soil and vegetation variables. The setup of the experiment was based on the following concept:

(1) ground measurements were made on some specific fields in order to calibrate and test procedures for assimilating remote sensing data;

(2) remote sensing measurements were made over the whole experimental area in order to extrapolate assimilation procedures to this area.

In this paper, we present the measurements performed at the ground level and give an overview of the soil, crop and climatic conditions that we encountered during the experiment.

\section{A GENERAL VIEW OF THE EXPERIMENT}

The experiment covered the whole growing season of winter and summer crops from October 1996 to November 1997. The experimental site was located near Avignon (SE of France, Fig. 1) in the Rhone valley ( $\mathrm{N} 43^{\circ} 47^{\prime}$ and $\mathrm{E} 4^{\circ} 45^{\prime}$; elevation: $8 \mathrm{~m}$ ). Its maximum dimension was approximately $4 \mathrm{~km}$ by $5 \mathrm{~km}$. It was a very flat area with fields large enough ( $200 \mathrm{~m}$ by $200 \mathrm{~m}$ ) to extract pure pixels from high spatial resolution satellites, as well as to implement atmospheric flux measurements (Fig. 2). The main crops were wheat (30\%), sunflower $(20 \%)$, orchard (15\%), corn, vegetable and forage (5\% each).

We chose to study 3 crops in more details because they have very different cultural cycles (wheat, sunflower and

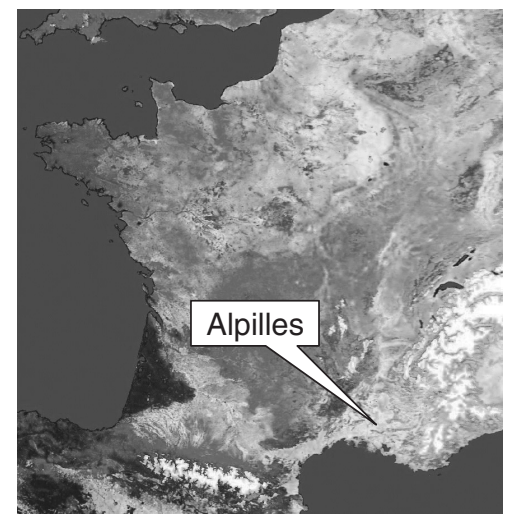

Figure 1. Location of the Alpilles-ReSeDA site on a AVHRR image of France.

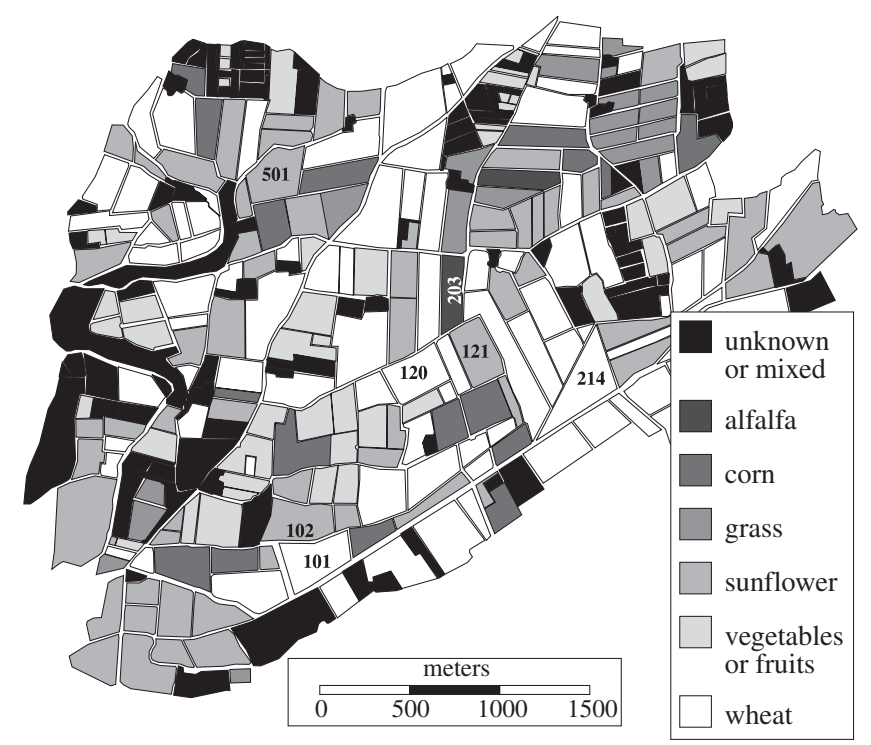

Figure 2. Land use map of the Alpilles test site ( $5 \mathrm{~km}$ by $4 \mathrm{~km})$. The seven calibration and validation fields are numbered $(101,102,120$, 121, 203, 214 and 501). 
Table I. The different types of investigated fields.

\begin{tabular}{lll}
\hline Crop & Type of field & Field number \\
\hline Wheat & Calibration & $\mathbf{1 0 1}$ \\
Sunflower & Calibration & $\mathbf{1 0 2}$ \\
Alfalfa & Calibration & $\mathbf{2 0 3}$ \\
Wheat & Validation & $\mathbf{1 2 0 2 1 4}$ \\
Sunflower & Validation & $\mathbf{1 2 1} \mathbf{5 0 1}$ \\
Wheat & remote sensing & 124208210300 \\
Sunflower & remote sensing & 104107205217304503 \\
Alfalfa & remote sensing & 306 \\
Corn & remote sensing & 112113125126311500504 \\
Grass & remote sensing & 301 \\
\hline
\end{tabular}

alfalfa, see Tab. I). A limited number of measurements were also performed on corn and grass fields (Tab. I). The spatial sampling strategy allowed a good characterization of the field scale, that revealed the variability within fields, and of a regional scale as may be observed by coarse resolution sensors. To calibrate and validate SVAT models we performed a continuous monitoring of surface energy balance components, surface temperature, albedo, soil water balance, standard meteorological data (wind speed, air humidity and temperature, rainfall and incident radiations), vegetation characteristics (height, biomass distribution and LAI), soil characteristics (temperature, moisture and water pressure profiles, surface soil moisture, surface roughness and surface dry bulk density). Additional measurements such as root density profiles, leaf water potential, leaf photosynthesis and stomatal conductance, soil hydrodynamic and thermal conductivities, dry bulk density profiles and soil texture, were performed at critical periods on some fields. Thus, most of the data required to run and test the different models were acquired during the experiment.

A detailed characterization was carried out on "calibration" fields (one wheat, one sunflower and one alfalfa field, see Tab. I). It will be used for the setup and the calibration of models and methods. A less detailed characterization was carried out on "validation" fields (two wheat and two sunflower fields, see Tab. I) which will be used for validating models and methods. Additional measurements were made on "remote sensing" fields concurrently with aircraft campaigns and some satellite image acquisitions. They will be used for testing further the procedures to estimate surface properties from remote sensing data (surface soil moisture, roughness, texture, dry bulk density, vegetation structure, biomass, height, water content, surface temperature, LAI and canopy cover fraction). Some of the general characteristics of the sampled fields are given in Table II.

A classical meteorological station was also settled to acquire climatic data that were consistent with the data that are usually available for an operational implementation of models. It must be noticed that the climatic conditions experienced during the experiment were characterized by a very wet winter and a very dry spring period, both situations quite unusual for the South-East of France's Mediterranean-type climate.

As the experiment was spread over two years, we defined a specific timescale giving the Day of the Experiment (DOE)

Table II. Field characteristics. (a) Soil type classes are silty clay for class 10, silty clay loam for 7 and silt loam for 4 (classes from Clapp and Hornberger [11]). These classes were derived from granulometry measurements in the 0-30 cm top soil layer. (b) Methods used for determining field capacity, wilting point and saturated water content are not described in this paper, but they can be found in Braud and Chanzy [4] and Olioso et al. [30]. (c) Due to the irrigation method (flooding) we do not know exactly the amount of this water supply. The day of experiment (DOE) corresponds to the number of days since January the first, 1996.

\begin{tabular}{|c|c|c|c|c|c|c|c|c|c|c|c|}
\hline Field number & 101 & 102 & 120 & 121 & 203 & 208 & 210 & 214 & 300 & 304 & 501 \\
\hline Soil type (a) & 10 & 7 & 10 & 10 & 7 & 10 & 7 & 10 & 4 & 7 & 4 \\
\hline Field capacity $(\mathrm{mm})(\mathrm{b})$ & 0.362 & 0.360 & 0.368 & 0.368 & 0.349 & - & - & 0.368 & - & - & 0.337 \\
\hline Wilting point $(\mathrm{mm})(\mathrm{b})$ & 0.239 & 0.217 & 0.239 & 0.229 & 0.227 & - & - & 0.241 & - & - & 0.146 \\
\hline Saturated water content $(\mathrm{mm})(\mathrm{b})$ & 0.381 & 0.380 & 0.380 & 0.400 & 0.360 & - & - & 0.390 & - & - & 0.442 \\
\hline Crop & wheat & sunflower & wheat & sunflower & alfalfa & wheat & wheat & wheat & wheat & sunflower & sunflower \\
\hline Cultivar & Armet & Lucil & Armet & Lucil & & Armet & Armet & Acalou & Armet & Lucil & Lucil \\
\hline Sowing (DOE) & 312 & 496 & 323 & 495 & - & 297 & 304 & 409 & 314 & 444 & 447 \\
\hline Harvest (DOE) & 547 & 642 & 548 & 631 & $\begin{array}{l}479 \\
529 \\
563 \\
597\end{array}$ & 548 & 530 & 563 & 540 & 603 & 607 \\
\hline Irrigation (mm) & no & no & $\begin{array}{l}100-120 \\
\text { (c) }\end{array}$ & no & no & no & no & no & no & no & no \\
\hline Date (DOE) & & & $457-460$ & & & & & & & & \\
\hline
\end{tabular}


Table III. Periods of measurements in the different calibration and validation fields (DOE: day of experiment corresponding to the number of days since January the first, 1996). * TDR measurements were also performed at the time of microwave remote sensing measurements outside of the nominal period.

\begin{tabular}{|c|c|c|c|c|c|c|c|c|c|}
\hline Field & 101 & 101 & 102 & 102 & 120 & 121 & 203 & 214 & 501 \\
\hline Crop & wheat & bare soil & bare soil & sunflower & wheat & sunflower & alfalfa & wheat & sunflower \\
\hline Neutron probe & $338-541$ & $618-703$ & $345-432$ & $509-648$ & $396-541$ & $485-635$ & $375-634$ & $436-555$ & $558-611$ \\
\hline Capacitance probe hourly & $443-541$ & $621-703$ & $393-432$ & $551-647$ & $403-537$ & - & $570-634$ & - & $558-611$ \\
\hline Capacitance probe daily & - & - & - & - & - & $563-635$ & $450-531$ & $451-554$ & - \\
\hline TDR probe & $345-533$ & $626-703$ & $345-424$ & $497-633$ & $378-536^{*}$ & $485-633^{*}$ & $345-591$ & $424-555^{*}$ & $451-606^{*}$ \\
\hline Tensiometers & $345-484$ & - & - & $507-568$ & $403-536$ & $509-633$ & $378-464$ & $439-555$ & - \\
\hline Soil temperature & $338-542$ & $620-700$ & $339-432$ & $501-649$ & $402-537$ & $514-635$ & $380-635$ & $431-557$ & $558-611$ \\
\hline Micrometeorological measurements & $338-542$ & $620-700$ & $346-432$ & $501-649$ & $402-537$ & $514-635$ & $388-635$ & $436-555$ & $558-611$ \\
\hline
\end{tabular}

which corresponded to the number of days since the first of January 1996. The time periods for each type of measurement performed in the various fields are presented in Table III.

\section{METEOROLOGICAL AND MICROMETEOROLOGICAL MEASUREMENTS}

\subsection{Central meteorological station}

Meteorological measurements were performed approximately at the center of the experimental site over a bare soil surface (North-West corner of field 205) with a 15-second time step and an averaging period of 20 minutes. Air temperature and vapor pressure were acquired at 2 meters above the ground using a Vaisala HMP35D platinum thermistor and capacitive probe. Soil temperatures were measured at 3 depths in the soil $(10 \mathrm{~cm}, 50 \mathrm{~cm}$ and $1 \mathrm{~m})$ with chromel-alumel thermocouples. Wind speed at 2 meters was measured by a Vector Instruments A100L2 cup anemometer. Wind direction and atmospheric pressure were also recorded.

Incident radiations were measured over the whole solar spectrum (Kipp pyranometer), the PAR region (Li-190SB Quantum sensor) and over the thermal domain (Eppley pyrgeometer). Incident diffuse solar radiation was also measured using a pyranometer with a shadow ring. Rainfall was recorded using an automatic rain gauge. All the sensors were calibrated before and after the experiment. A comparison of the data against the data acquired in Avignon (20 kilometers to the North of the site) did not show any major failure. During the last month of the experiment it was necessary to dismantle the meteorological site and a reconstruction of the meteorological data was done from the Avignon and Saint-Rémy (10 km to the East of the site) meteorological network measurement stations. Daily data are presented in Figure 3.

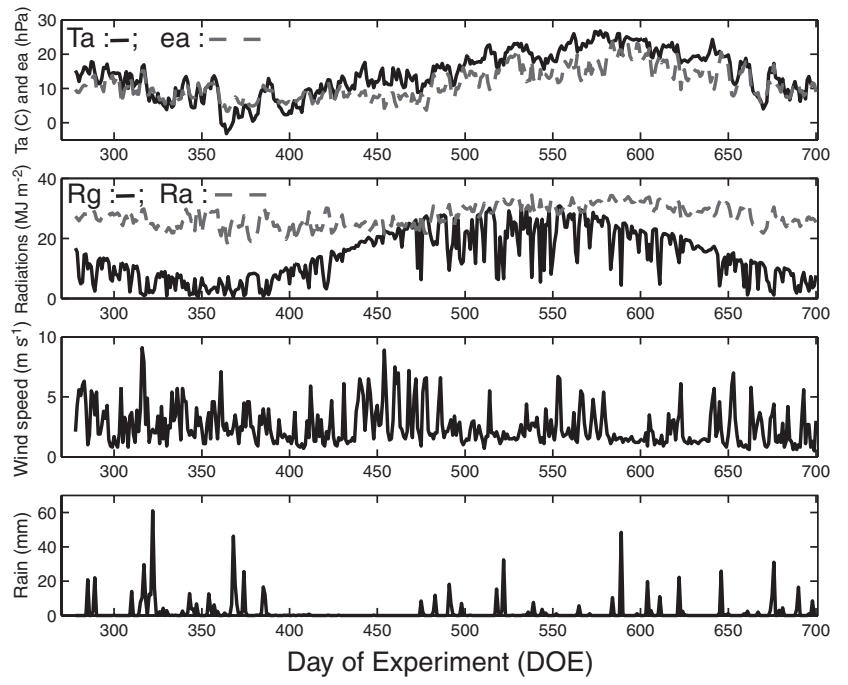

Figure 3. Meteorological conditions during the experiment (Ta is the daily mean air temperature, ea the daily mean air vapor pressure, $\mathrm{Rg}$ is the daily incoming solar radiation and $\mathrm{Ra}$ is the daily incoming atmospheric radiation). The day of experiment (DOE) corresponds to the number of days since January the first, 1996.

\subsection{Measurements of in-situ meteorological variables and fluxes}

Micrometeorological measurements were performed over calibration and validation fields with a time step of $15 \mathrm{sec}-$ onds and an averaging period of 20 minutes. The instrumentation was installed at least 100 meters from the upwind edges of the fields. It consisted of air temperature measurements using thermocouples (chromel-alumel) in comparison with reference temperature measurements by platinum thermistors, relative humidity measurements by means of Vaisala HMP35D capacitive probes (these measurements were transformed into vapor pressure values), and wind speed measurements by means of Vector Instruments A100L2 cup 
anemometers. All the instruments were calibrated and inter-compared before and after the experiment. The measurements were performed at two levels above the canopy (at about 1.5 times and 3 times the canopy height) with the idea of computing turbulent heat fluxes by means of the Bowen ratio method or the combined aerodynamical method. Vapor pressure gradients were obtained by pumping air alternatively at the two measurement levels using a system inspired by [8]. However, failures in the instrumentation were frequent, generating errors in the system for measuring vapor pressure and temperature gradients which did not allow computation of the fluxes with good accuracy: at least half of the measurements were rejected on the basis of the filtering method proposed by Ohmura [26]. Additional flux measurements were performed as a backup for the previous Bowen ratio apparatus:

- mono-dimensional eddy-correlation systems (Campbell CA27T) were used as often as possible and generated a significant set of sensible heat flux data over the three wheat fields and the sunflower field 102;

- measurements using 3D sonic anemometers (Gill R3) were also performed for some days in June over fields 120 and 121 (see $[21,22]$ );

- commercial Bowen ratio systems (Campbell) based on dew point hygrometer measurements, or on direct gradient measurements by means of a LiCOR 6262 gas analyzer also provided some data on fields 101 and 102 (this system also provided $\mathrm{CO}_{2}$ flux data).

Comparison of different types of measurements is presented in Figure 4. It shows large scatters in the data and in some cases overestimations of sensible heat flux by the home-made Bowen ratio system. Further analysis of the data showed that it was possible to provide less scattered data using a smoothing procedure based on the assumption that heat fluxes to net radiation ratios were constant throughout the day (Fig. 4). It also showed that latent heat flux estimates have good behavior in the long term.

Net radiation measurements were performed using Rebs (Radiation and energy balance systems, Inc.) Q7 instruments (fields 101, 102 and 120) and Crouzet-INRA devices (fields 121, 203, 214 and 501) set at a height of 3 meters (over wheat and alfalfa fields) or a height of 6 meters (over sunflower fields). These instruments were inter-calibrated and compared with two reference instruments, which were calibrated by the constructor, just before and just after the experiment: root mean square differences were lower than $8 \mathrm{~W} \cdot \mathrm{m}^{-2}$ between the different sensors. The sensitivity of the Q7 sensors to wind speed was accounted for by using the procedure given in the instruction manual. A comparison of net radiation measurements with calculation from measurements of reflected solar radiation, surface temperature and incoming atmospheric radiation made it possible to correct data for possible problems of sensor leveling (less than $10 \%$ of the data).

Measurements of ground heat flux were performed using heat flow transducers (Rebs HFT-1 and HFT 3.1) installed at a depth of $5 \mathrm{~cm}$. They were corrected by the change in thermal storage from the transducer level to the soil surface, us- ing two soil temperature measurements (see Sect. 5) and estimates of the soil heat capacity. The latter was computed from dry bulk density and TDR soil moisture measurements in the layer between the soil surface and the transducers. The calibration done by the manufacturer was used since it was representative of the soil in the ReSeDA experimental site. The transducers were installed at four locations within an area of about $2 \mathrm{~m}$ by $2 \mathrm{~m}$ and accounting for the variability due to the row. Comparison of corrected measurements of ground heat flux against fluxes computed by a heat storage method was satisfactory when the zero flux plan was not too close to the surface. Occasional comparison with transducers settled close to the surface (less than half a centimeter) gave similar results.

Incident solar radiation was measured on two fields (101 and 121) giving very similar values to the central meteorological measurements site. Reflected solar radiation was measured over every field using Kipp pyranometers (fields 101, 121 and 203) and Skye SP1110 pyranometer sensors (fields 102, 120, 214 and 501). Instruments were settled at the same height as net radiation sensors. All these instruments were inter-calibrated before and after the experiment, and compared with a newly calibrated reference sensor at the Avignon INRA centre. However, the spectral response of the Skye instruments was not adequate for measuring reflected solar radiation and a correction procedure was required in order to obtain accurate values [15]. This procedure was based on simulations done by a radiative transfer model. As information on spectral distribution of incident radiation in cloudy conditions was not available, this procedure was not implemented for days with a diffuse fraction in the solar radiation above 0.50 .

Surface temperatures were measured using Heimann KT15 thermal radiometers (fields 101, 102 and 120) and Heimann KT17 thermal radiometers (fields 121, 203, 214 and 501), which were installed at the same height as net radiation sensors. These instruments measured the radiation originating (emission plus reflection) from the canopy in the 8 to $14 \mu \mathrm{m}$ waveband. Measurements were made with a $18.5^{\circ} \mathrm{ze}-$ nith angle to the vertical in the south direction; they had a 16 degree field of view $(8.6 \mathrm{~m}$ - or $2.6 \mathrm{~m}$ - spot at the soil surface depending on the sensor height). They were calibrated by looking at a black body at various temperatures. Output signals were directly converted into temperatures using a regression equation. The effect of ambient temperature on KT17 measurements was taken into account during the calibration and the measurements, using a temperature probe installed in the body of the instrument. No such effect was found for KT15 sensors. The effects of emissivity and reflection of atmospheric radiation were not corrected. Thus, only thermal brightness temperatures were provided.

Cimel CE-312 thermal infrared radiometers were also used to address the brightness temperature directional variations of vegetated areas. This was done on three fields (203, 120 and 102) for 2 days in each field in June and July. Two radiometers were looking simultaneously at the same surface (same IFOV) under two different directions (nadir and $55^{\circ}$ 

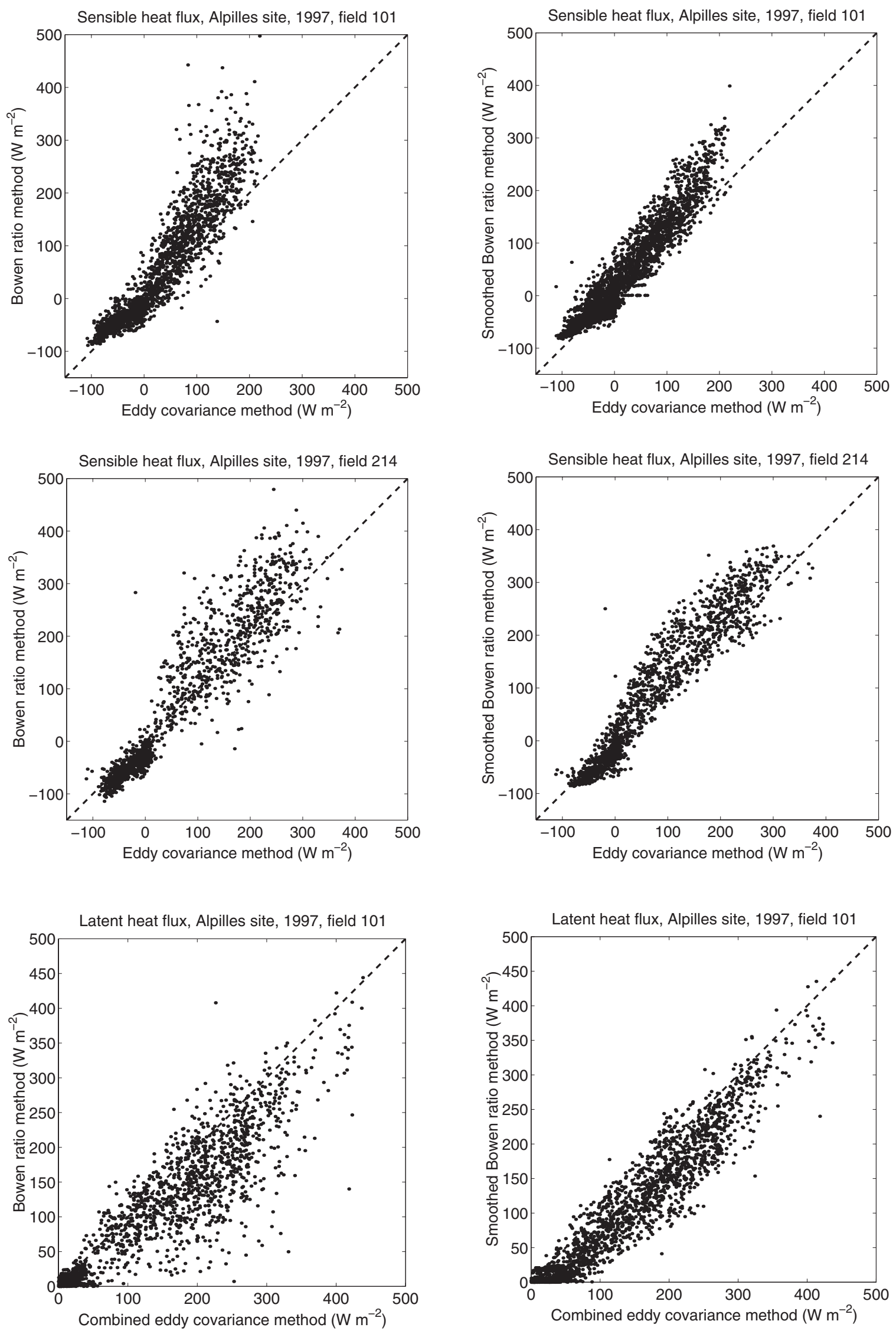
forward zenith angle to mimic the ATSR instrument capacities on ERS satellites). The calibration was done on-site using black bodies viewed by the radiometers every 2 minutes. The whole acquisition process was automated, using CIMEL robots.

Emissivity measurements in the 8-14 $\mu \mathrm{m}$ window were performed in April and July using the box method on bare soil, plants and crops (30 measurements for each type of surface). They are detailed in [12]. Soil samples were also collected and measurements with a four band CIMEL radiometer (CE-312) were performed in the laboratory, giving quite similar values to the field measurements and showing a moderate spectral contrast in the $8-14 \mu \mathrm{m}$ window. This was also confirmed by spectra measurements carried out at the Jet Propulsion Laboratory.

\section{PLANT MEASUREMENTS}

Leaf Area Index measurements were performed using two different methods: (i) the green leaf area of 6 samples $\left(0.25 \mathrm{~m}^{2}\right)$ was measured using a planimeter, every week or two weeks; (ii) LiCOR LAI2000 measurements (ten measurements at ten random locations within each field) were also performed every two weeks as soon as the canopy was developed enough. Large differences were noticed between the two types of measurements (see an example in Fig. 5). They might be explained either by the fact that the LAI 2000 measurements included the effect of stems and ears (notice, however, that these measurements were made by setting the instrument above the senescent leaf layer in order to account only for the green part of the canopy), or by non-ideal conditions for the LAI2000 measurements, which were made in some cases under clear sky conditions. Biomass measurements were performed at the same time as planimetric measurements, including fresh biomass, dry matter, and their repartition by organs (leaves, stems, flowers and ears).

Plant heights were measured using a simple ruler on 20 to 50 individual plants every one or two weeks.

Stomatal conductance and leaf photosynthesis were measured throughout the day at least once every month by means of a CIRAS (PPSystem) or a Li6400 (LiCOR) gas exchange analysis system on the wheat and sunflower calibration fields. These measurements were associated with measurements of leaf water potential using a Schollander chamber.

Root density measurements were performed on two occasions: on DOE 402, fields 101 and 120 were sampled at 6 locations (row + between rows) down to $60 \mathrm{~cm}$ using a drilling

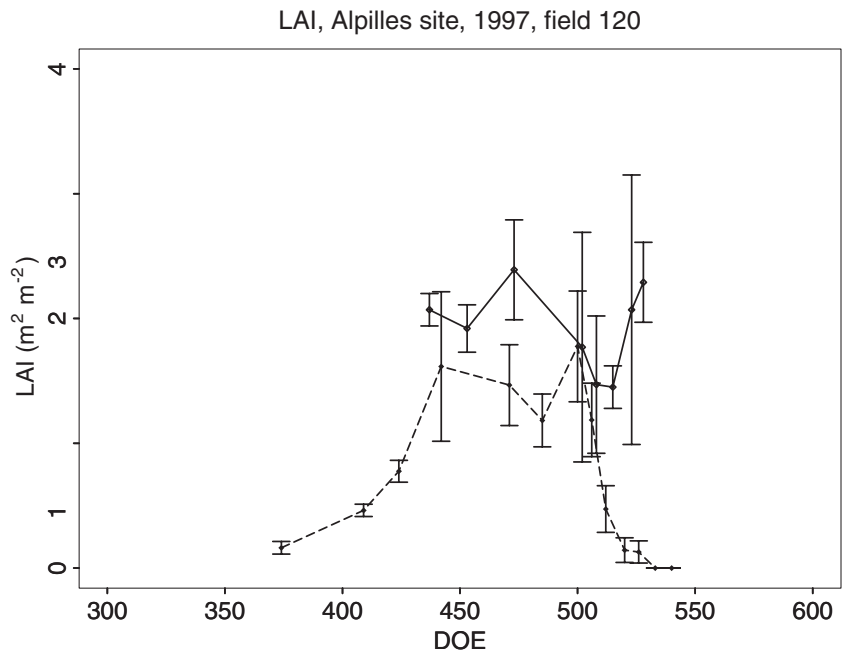

Figure 5. LAI measurements over field 120 (and standard deviation). Solid line corresponds to LAI2000 estimates and dashed line to destructive planimeter measurements. The day of experiment (DOE) corresponds to the number of days since January the first, 1996.

auger ( $7.5 \mathrm{~cm}$ diameter and $15 \mathrm{~cm}$ long); and on DOE 500 and 527 , a hole was opened down to $1.5 \mathrm{~m}$ on field 101 , and samples were collected every $11 \mathrm{~cm}$ with a $13 \mathrm{~cm}$ diameter auger. The samples were washed through sieves to extract the roots which were weighed. The root length density was also measured using an image analysis system.

\section{SOIL MEASUREMENTS}

Soil measurements were performed to monitor the soil moisture and temperature status in the root zone and near the soil surface throughout the experiment, and to characterize the hydrodynamical properties of the investigated fields. Thus, it was possible to have information on the factors controlling plant transpiration and soil evaporation as well as water and heat transfers in the soil. The measurement periods are given in Table III.

Soil granulometry was assessed in various fields for the 0-30 cm soil layer and in the 40-60 cm layer on calibration and validation fields. For each field and each layer, 7 samples were collected, mixed, and then the fractions of 8 granulometric classes were determined.

Figure 4. Comparison of heat flux measurements by means of different instruments and on different fields. Root Mean Square Difference between Bowen ratio estimates of sensible heat flux and eddy correlation measurements were as follows:

Field 101, diurnal data, Bowen ratio method: $71 \mathrm{~W} \cdot \mathrm{m}^{-2}$; smoothed Bowen ratio method: $50 \mathrm{~W} \cdot \mathrm{m}^{-2}$

Field 101, diurnal+night data, Bowen ratio method: $51 \mathrm{~W} \cdot \mathrm{m}^{-2}$; smoothed Bowen ratio method: $36 \mathrm{~W} \cdot \mathrm{m}^{-2}$

Field 214, Bowen ratio method, diurnal data: $73 \mathrm{~W} \cdot \mathrm{m}^{-2}$; smoothed Bowen ratio method: $55 \mathrm{~W} \cdot \mathrm{m}^{-2}$

Field 214, Bowen ratio method, diurnal data+night: $50 \mathrm{~W} \cdot \mathrm{m}^{-2}$; smoothed Bowen ratio method: $39 \mathrm{~W} \cdot \mathrm{m}^{-2}$

For latent heat flux, the combined eddy covariance data were computed as $\mathrm{LE}=\mathrm{Rn}-\mathrm{G}-\mathrm{H}$, with $\mathrm{H}$ measured using the eddy covariance method. 
The dry bulk density $\left(\mathrm{g} \cdot \mathrm{cm}^{-1}\right)$ was measured, using three methods: (i) transmission of gamma rays for the surface soil layers $(0-40 \mathrm{~cm})$; (ii) scattering of gamma rays for the deeper layers, and (iii) the cylinder method (mainly implemented near the soil surface). The source and the detector of the gamma ray transmission probe (built by Laboratoire Central des Ponts et Chaussées - LCPC, Angers, see [1]) were introduced into two different vertical access tubes 20 to $30 \mathrm{~cm}$ apart and measurements were made every $5 \mathrm{~cm}$ from 2.5 to $42.5 \mathrm{~cm}$ depth or from 2.5 to $7.5 \mathrm{~cm}$ depth (5 to 6 replications per field). The probe was calibrated on blocks of known density once before the experiment. Cylinder measurements were made using various cylinder sizes between 100 and $150 \mathrm{~cm}$ at 3 to 6 locations. Measurements in the ploughed layer (0-10 $\mathrm{cm}$ layer), either by cylinder or transmission probe, were made once between each tillage operation at 3 to 6 locations. The measurements with the gamma ray scattering probe (SOLO 40 from Nardeux Humisol) were made at the time of installation of the neutron probe access tube every $10 \mathrm{~cm}$ from $25 \mathrm{~cm}$ down to $135 \mathrm{~cm}$ in calibration and validation fields. The SOLO40 probe was calibrated by comparison with LCPC and cylinder measurements.

Soil moisture profiles down to $1.40 \mathrm{~m}$ were measured using neutron probes at two locations in each field (3 locations in field 101 during the wheat crop). Measurements were made every $10 \mathrm{~cm}$ from $5 \mathrm{~cm}$ down to $135 \mathrm{~cm}$ and every 4 to 15 days. Two different probes (Solo 40 and Solo 25 from Nardeux-Humisol) were used. They were calibrated against averaged gravimetric measurements of 5 profiles in order to get a soil moisture value representative of the field (one profile was made in the vicinity of each access tube and the others were spread over the field). Gravimetric moisture was converted to volumetric moisture using the soil dry bulk density measurements. The average of the two (or three) tubes was used as representative of the soil moisture of the field. Soil moisture profiles were also measured by means of capacitance probes (HMS 9000 from SDEC-France [9, 16]), but over a shorter period of time (usually starting in March). The sensors were logged to the Campbell data logger used for atmospheric measurements and provided hourly (sometimes only daily) measurements of soil moisture. Measurements were made at two locations and at $2.5 \mathrm{~cm}, 7.5 \mathrm{~cm}, 15 \mathrm{~cm}$, $25 \mathrm{~cm}, 40 \mathrm{~cm}, 65 \mathrm{~cm}$ and $100 \mathrm{~cm}$ depth on fields 101 and 102; on the other fields, only measurements at 2.5 (120 and 214) and at 2.5 and $7.5 \mathrm{~cm}$ (121 and 501) were performed. As for neutron probe measurements, the measurements were calibrated in order to be representative of the field average moisture for a given soil layer, as proposed by Chanzy et al. [9]. The effect of temperature on the measurements was taken into account following the procedure described by [2]. An example of the evolution of the measurements by the various methods is presented in Figure 6.

Surface soil moisture was monitored using various procedures. Capacitive probes provided hourly data on fields 101, $102,120,121,203,214$ and 501. Gravimetric sampling and TDR measurements provided data on a larger number of fields in order to extend the spatial sampling, but with a lower temporal sampling:

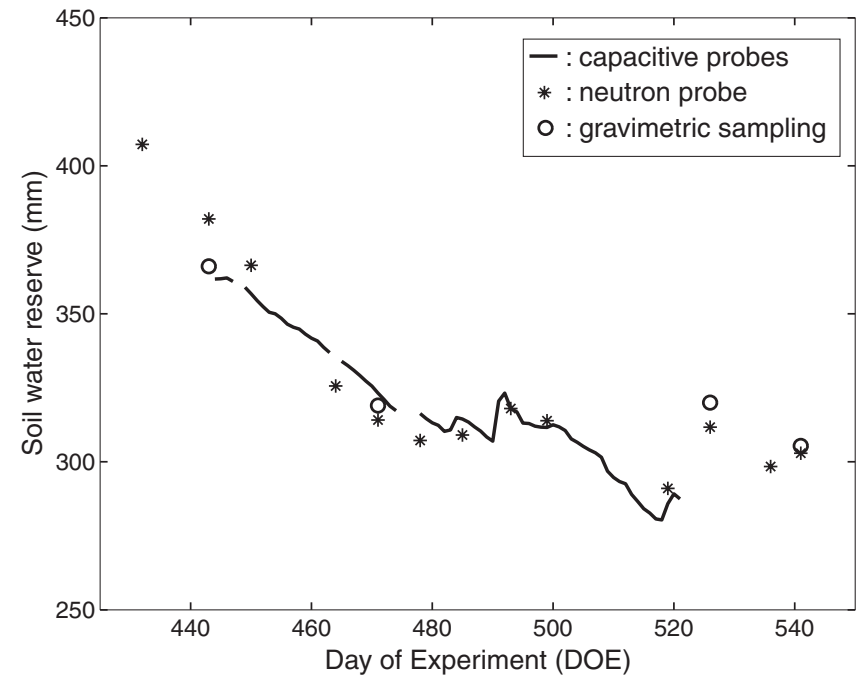

Figure 6. Comparison of water reserve in the $0-120 \mathrm{~cm}$ soil layer as obtained by different methods of measurement on field 101. The day of experiment (DOE) corresponds to the number of days since January the first, 1996.

- gravimetric measurements were made by sampling three layers: $0-1 \mathrm{~cm}, 1-5 \mathrm{~cm}$ and $5-10 \mathrm{~cm}$. Five to fifteen replications were done, depending on the field and the day of measurements. The volumetric water content was computed on the field scale by multiplying the average gravimetric water content by the field average of the dry bulk density. These measurements were only made at the time of the microwave remote sensing measurements.

- TDR measurements were made by a TRASE model from Soil Moisture Equipment using buriable wave guides which consisted of three $20 \mathrm{~cm}$ needles. In each field, 5 probes were installed horizontally at a depth of $2.5 \mathrm{~cm}$, and left in the field between two tillage operations. A calibration was done for each field and for each period of probe installation by relating TDR readings to the mean soil volumetric water content data collected in the top five soil centimeters, using the gravimetric method. TDR measurements were made almost every week on calibration and validation fields. They were also performed at the time of the microwave remote sensing data acquisitions in remote sensing, calibration and validation fields.

Profiles of soil water potential down to $1.30 \mathrm{~m}$ were measured with tensiometers fitted out with either mercury manometers or electronic manometers (SDEC SKT850C). Two sites of measurements were installed close to neutron probe access tubes. At each site, a set of 5 tensiometers $(20 \mathrm{~cm}$, $50 \mathrm{~cm}, 80 \mathrm{~cm}, 110 \mathrm{~cm}$ and $130 \mathrm{~cm}$ ) was installed in the validation fields. On calibration fields, two additional depths were sampled $(10 \mathrm{~cm}$ and $30 \mathrm{~cm})$. The calibration of SKT850C manometers was done before the experiment and accounted for temperature effects. SKT850C provided hourly measurements, while measurements with mercury manometers were made at least every week. Measurements 
were performed within the $0-8 \mathrm{~m}$ tensiometric range. At the bottom of the profile, two tensiometers were installed at 110 and $130 \mathrm{~cm}$ to measure the soil water potential gradient at $120 \mathrm{~cm}$ in order to implement the Darcy law to estimate the drainage flow.

Soil temperature profiles were measured either by chromel/alumel thermocouples (fields 101, 102, 203 and 120 ) or platinum resistances (fields 121, 214 and 501). The reference measurements for the thermocouples were made using platinum resistances in a PVC box buried in the soil at a depth varying between 20 and $30 \mathrm{~cm}$. Temperature probes were installed in each field at $0.5 \mathrm{~cm}$ (2 sensors), $1.0 \mathrm{~cm}$, $2.5 \mathrm{~cm}$ (2 sensors), $7.5 \mathrm{~cm}, 15 \mathrm{~cm}, 25 \mathrm{~cm}, 50 \mathrm{~cm}$ and $100 \mathrm{~cm}$. The probes were calibrated at various temperatures prior to the experiment.

Hydrodynamical and thermal properties were assessed by combining some of the above measurements and specific methods. Retention curves may be obtained by relating soil moisture to soil water potential using the in situ neutron probe and tensiometric measurements presented above, or measurements acquired when determining the hydraulic conductivity by the Wind method. Specific pressure chamber measurements made it possible to enlarge the range of water potential which was limited to $8 \mathrm{~m}$ with tensiometers. Measurements with the pressure chamber method (using a pressure chamber from Soil Moisture Equipment Corporation) were made both on non-disturbed soil clods (1 to $3 \mathrm{~cm}$ ) and on disturbed soil sieved between 0 and $2 \mathrm{~mm}$. Samples were collected in October 1997 from field 101, 120, 201, 203, 214 and 501 for two different soil layers $(0-20 \mathrm{~cm}$ and $40-60 \mathrm{~cm})$. For each field and soil layer, samples from 5 locations were mixed together. After being wetted and drained of excess water, the mixed soil samples were put into the chamber at a given pressure until an equilibrium was obtained. Then, the moisture of the soil sample was measured. Each measurement was duplicated. This was done at different pressure levels from $0.7 \mathrm{~m}$ to $150 \mathrm{~m}$.

Soil hydraulic conductivity measurements were made on undisturbed cores using the Wind method in the laboratory. This method only required a balance and tensiometers and provided measurements of the hydraulic conductivity for soil water potential between $-8 \mathrm{~m}$ and $0 \mathrm{~m}$ [39]. The measurements were made on cylindrical soil cores with a diameter of $15 \mathrm{~cm}$ and a height of $7 \mathrm{~cm}$. The balance and tensiometer were calibrated prior to the measurements. This was done at different depths down to $120 \mathrm{~cm}$ on field 101 (DOE 502 and 452), $50 \mathrm{~cm}$ on field 102 (DOE 481) and $25 \mathrm{~cm}$ on field 203 (DOE 481). In situ measurements using infiltrometers and simplified infiltration tests (the Beerkan method proposed by Haverkamp et al., cited in Braud [3]) were performed in the fields, providing estimation of the saturated hydraulic conductivity.

Thermal conductivity was measured using the line source method described by [23] on field 101, 102, 120, 121 and 214 at different depths $(5 \mathrm{~cm}$ to $45 \mathrm{~cm})$ and at 3 to 15 locations.

\section{SOME ILLUSTRATIONS}

During the experiment, the meteorological conditions were characterized by a very wet winter and dry spring and summer (see Figs. 3, 7). The spring was very dry since no rain occurred for almost 3 months between 21 st of January (DOE 387) and 18th of April (DOE 474). After that period, the rain amount was quite normal for the area $(290 \mathrm{~mm}$ from April to the end of October), but it did not compensate for the large potential evapotranspiration that occurred $(914 \mathrm{~mm}$ for the same period).

Table IV and Figures 8 and 9 show some aspects of the variability of the investigated soils in the area (see also Tab. II). Most soils have a high clay content, the lower values being located in the North-West and the highest in the South-East. This high clay content generated low hydraulic conductivity values and strong water retention. Hydraulic conductivities were very close for the three investigated fields. Apparent differences in Figure 8 actually reflect the retention curve differences: field 101 appeared to be less conductive than fields 102 and 203 (this was in agreement with textural data) and, for each field, the conductivity increased with depth. A higher value of hydraulic conductivity might be expected for fields with a lower clay content, such as field 501. Such a result was obtained with the Beerkan method [3]. For all fields, in situ infiltration tests (infiltrometers and the Beerkan method) led to saturated hydraulic conductivity several orders of magnitude higher than with the Wind method. This result was linked to the presence of cracks in the soil (they were very large at the surface), caused by shrinkage of the dry clay soil. The retention curves in Figure 9 exhibited a variability in the top soil layer which is also in agreement with soil texture (lower water content at a given water potential for the lowest clay content). In deeper layers, differences between fields were lower, probably because of a more homogeneous clay content at that depth over the area.

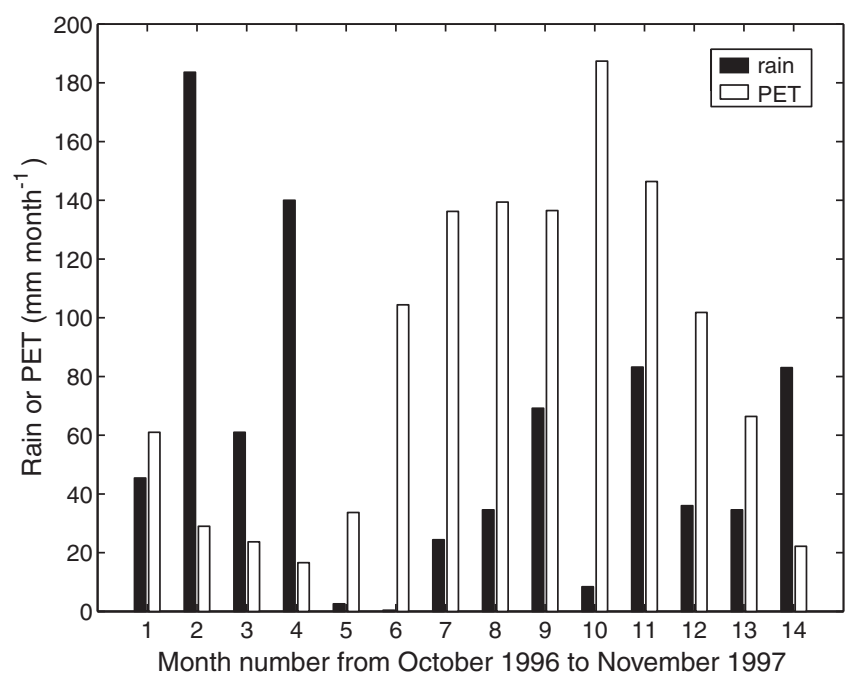

Figure 7. Cumulated rain (left bars) and potential evapotranspiration (PET, right bars) for each month of the experiment. 


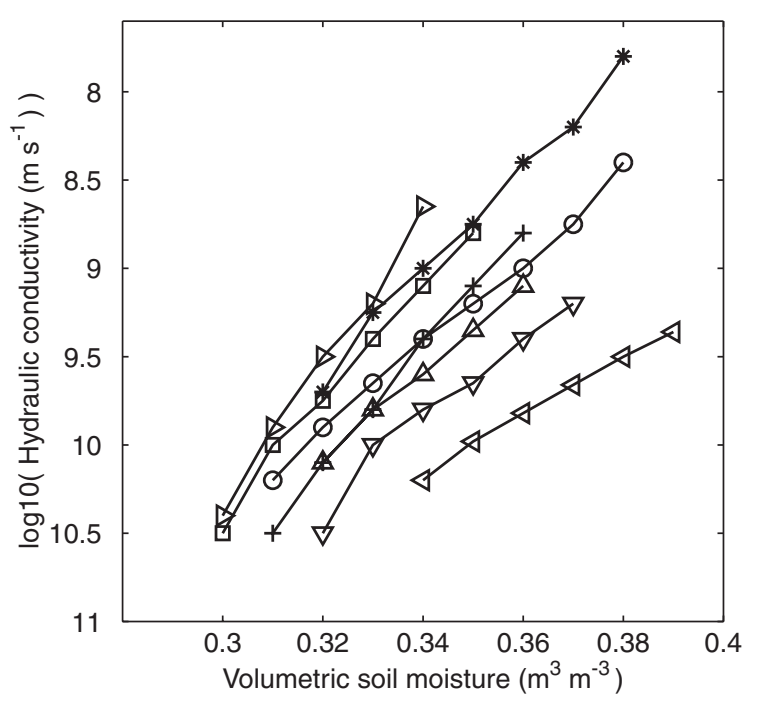

Figure 8. Mean hydraulic conductivity measured using the WIND method at different depths on calibration fields:
$\triangleright$ : field 101
$10-17 \mathrm{~cm}$
$\nabla$ : field 10
$28-35 \mathrm{~cm}$
$\triangleleft$ : field 101
$60-67 \mathrm{~cm}$
$\otimes$ : field 101
$120-127 \mathrm{~cm}$
+ : field 102
$10-17 \mathrm{~cm}$
*: field 102
$50-57 \mathrm{~cm}$
O: field 203
$3-10 \mathrm{~cm}$
$\square$ : field 203
$23-30 \mathrm{~cm}$

Table IV. Soil granulometry (average) for different fields and different layers.

\begin{tabular}{|c|c|c|c|c|c|}
\hline $\begin{array}{l}\text { Field } \\
\text { number }\end{array}$ & $\begin{array}{l}\text { Depth } \\
(\mathrm{cm})\end{array}$ & $\begin{array}{l}\text { Clay } \\
(\%)\end{array}$ & $\begin{array}{l}\text { Silt } \\
(\%) \\
\end{array}$ & $\begin{array}{l}\text { Sand } \\
(\%)\end{array}$ & $\begin{array}{c}\text { Organic } \\
\text { matter } \\
\left(\mathrm{g} \cdot \mathrm{kg}^{-1}\right)\end{array}$ \\
\hline 101 & $0-30$ & 42.2 & 53.3 & 4.5 & 25.3 \\
\hline 101 & $40-60$ & 48.0 & 49.9 & 2.1 & \\
\hline 102 & $0-30$ & 37.6 & 57.4 & 5.0 & \\
\hline 120 & $0-30$ & 40.7 & 54.1 & 5.2 & 22.0 \\
\hline 120 & $40-60$ & 42.8 & 53.3 & 4.5 & \\
\hline 121 & $0-30$ & 41.5 & 52.5 & 6.0 & 23.2 \\
\hline 125 & $0-20$ & 45.9 & 50.1 & 4.0 & \\
\hline 203 & $0-30$ & 32.8 & 53.9 & 13.3 & 21.5 \\
\hline 203 & $40-70$ & 43.2 & 51.6 & 5.2 & \\
\hline 205 & $0-30$ & 36.7 & 58.0 & 5.3 & \\
\hline 208 & $0-30$ & 42.5 & 52.9 & 4.6 & 24.1 \\
\hline 210 & $0-30$ & 39.7 & 57.0 & 3.3 & 23.0 \\
\hline 214 & $0-30$ & 46.1 & 50.3 & 3.6 & 26.0 \\
\hline 214 & $40-70$ & 50.9 & 47.4 & 1.7 & \\
\hline 300 & $0-30$ & 23.4 & 64.0 & 12.6 & 19.6 \\
\hline 304 & $0-30$ & 28.2 & 64.3 & 7.5 & 23.9 \\
\hline 501 & $0-30$ & 17.0 & 53.8 & 29.2 & 14.6 \\
\hline 501 & $40-70$ & 19.3 & 55.2 & 25.5 & \\
\hline
\end{tabular}
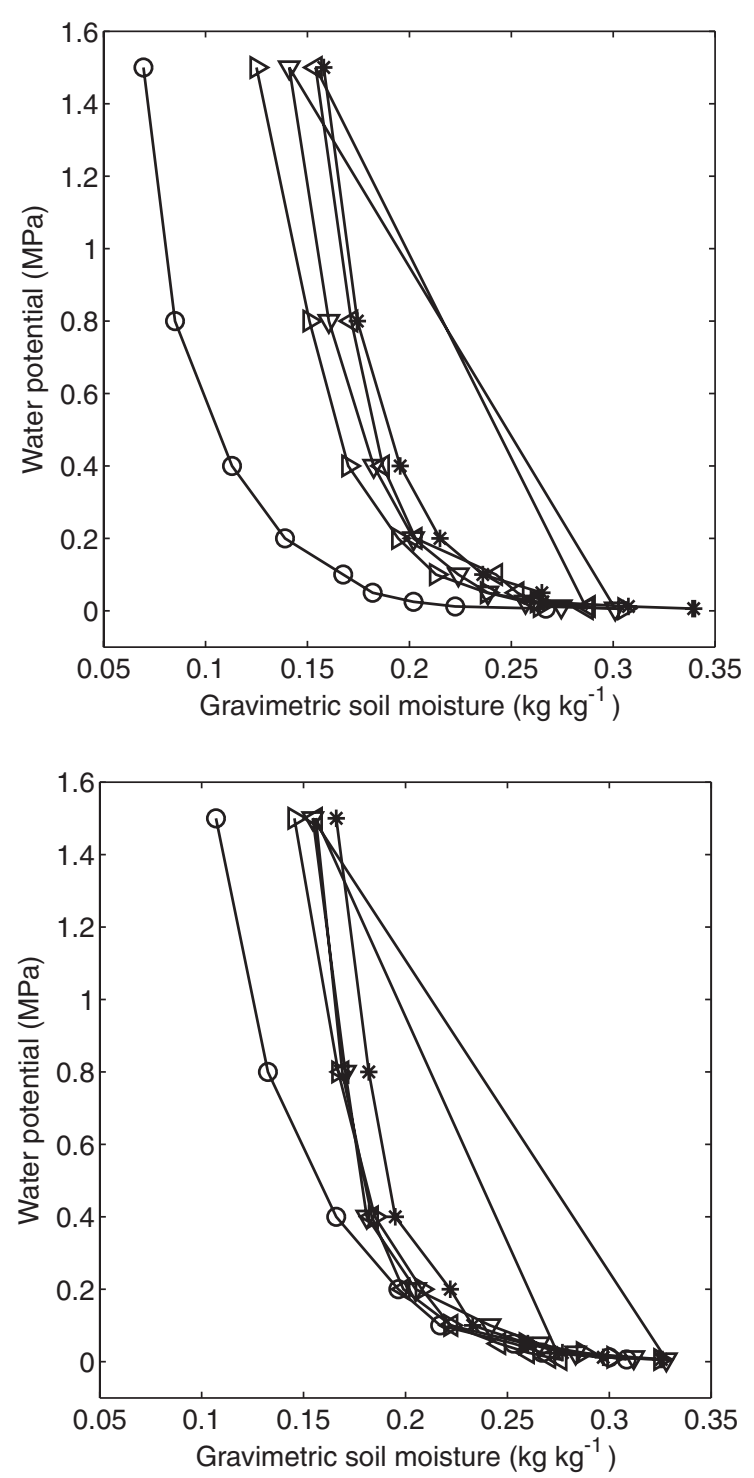

Figure 9. Retention curves measured with the pressure chamber method on sieved samples. Top graph: 0-20 cm soil layer; Bottom graph: $40-60 \mathrm{~cm}$ depth $(\triangle=$ field $101 ; \nabla=$ field $120 ; \triangle$ field 201 ; $\triangleleft$ field 203; * = field 214; $\bigcirc=$ field 501).

Figure 10 shows the evolution of LAI (planimeter method) during the experiment for various fields. Wheat and sunflower crops presented low values which never reached 3. This was explained by the dramatic climatic conditions that occurred at the end of winter and the low amount of rain in spring and summer. The highest wheat LAI were obtained in fields 120, 210 and 300. Field 120 was irrigated once, at the end of March. Around $100 \mathrm{~mm}$ were given just by flooding the field from its East side. The other fields were not irrigated. The highest sunflower LAI, hardly above 2, were obtained on field 501. The sunflower crops suffered from very 
difficult conditions at the time of sowing and emergence: sowing was done either in very dry conditions (field 501 on DOE 447) or very late (fields 102 and 121 on DOE 496). The low LAI values also reflected a high heterogeneity, with large zones with almost no plants or very small plants. The sunflower crops were not irrigated. The alfalfa presented a high value of LAI in spring (4.5). After being cut (4 times), the crop reached lower values of LAI.

Figure 11 presents the evolution of soil moisture in the $0-140 \mathrm{~cm}$ soil layer for calibration and validation fields. High
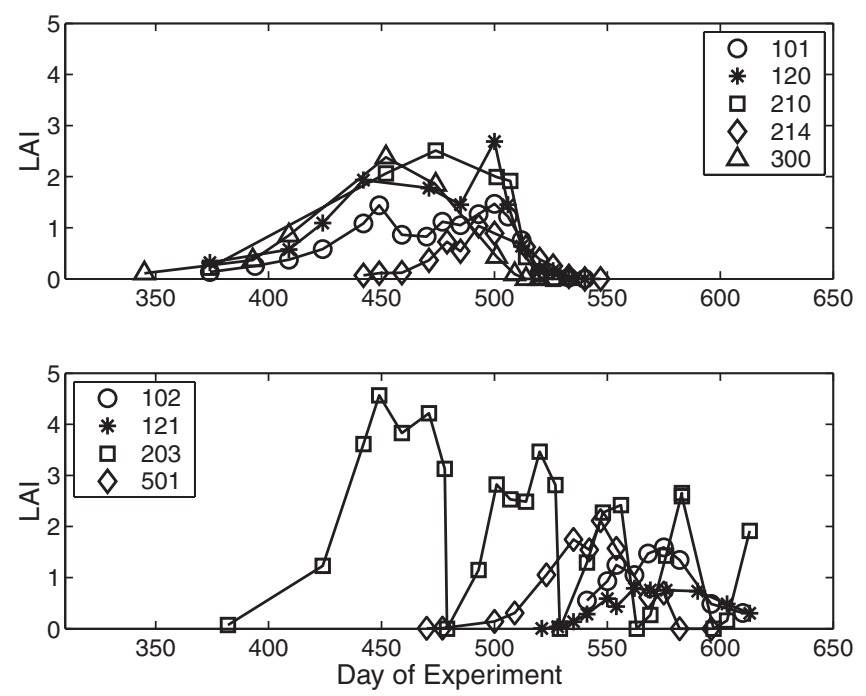

Figure 10. Measured LAI (planimeter) for different wheat fields (top graph: 101, 120, 210, 214 and 300), alfalfa (bottom graph: 203) and sunflower fields (bottom graph: 102, 121 and 501). The day of experiment (DOE) corresponds to the number of days since January the first, 1996.
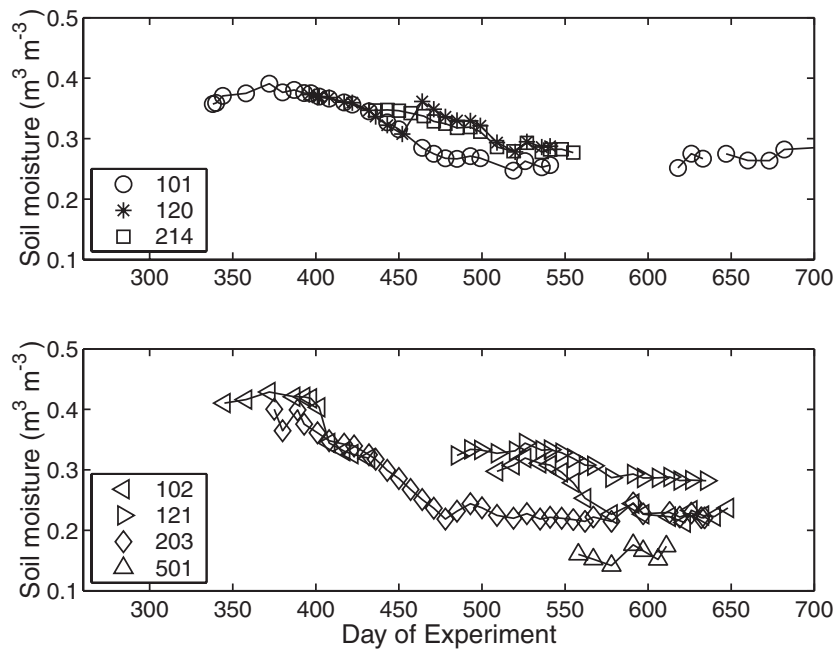

Figure 11. Evolution of soil moisture in the $0-140 \mathrm{~cm}$ soil layer for the calibration and the validation fields (neutron probe measurements). The day of experiment (DOE) corresponds to the number of days since January the first, 1996. water contents (saturation) were noticed in winter due to the high amount of rain. Soil moisture decreased after that period because of soil evaporation (and drainage) and the installation of vegetation. For the various types of crops, differences between fields appeared clearly. In the case of wheat crops, the soil moisture in fields 101 and 120 had the same evolution until the irrigation of field 120 totally re-watered the $0-140 \mathrm{~cm}$ soil layer. The late sowing and the low vegetation amount on field 214 generated a slower decrease in moisture. Only field 101 was close to its wilting point (see Tab. II). For sunflower, a lower decrease in soil water content occurred for field 121 than for field 102, which might be due to sparser vegetation. The low value of soil moisture in field 501 might be due to the type of soil, which contained less clay and had a lower wilting point (see Tab. II). The soil moisture in fields 102 and 501 reached the wilting point values, which was also the case for the alfalfa field.
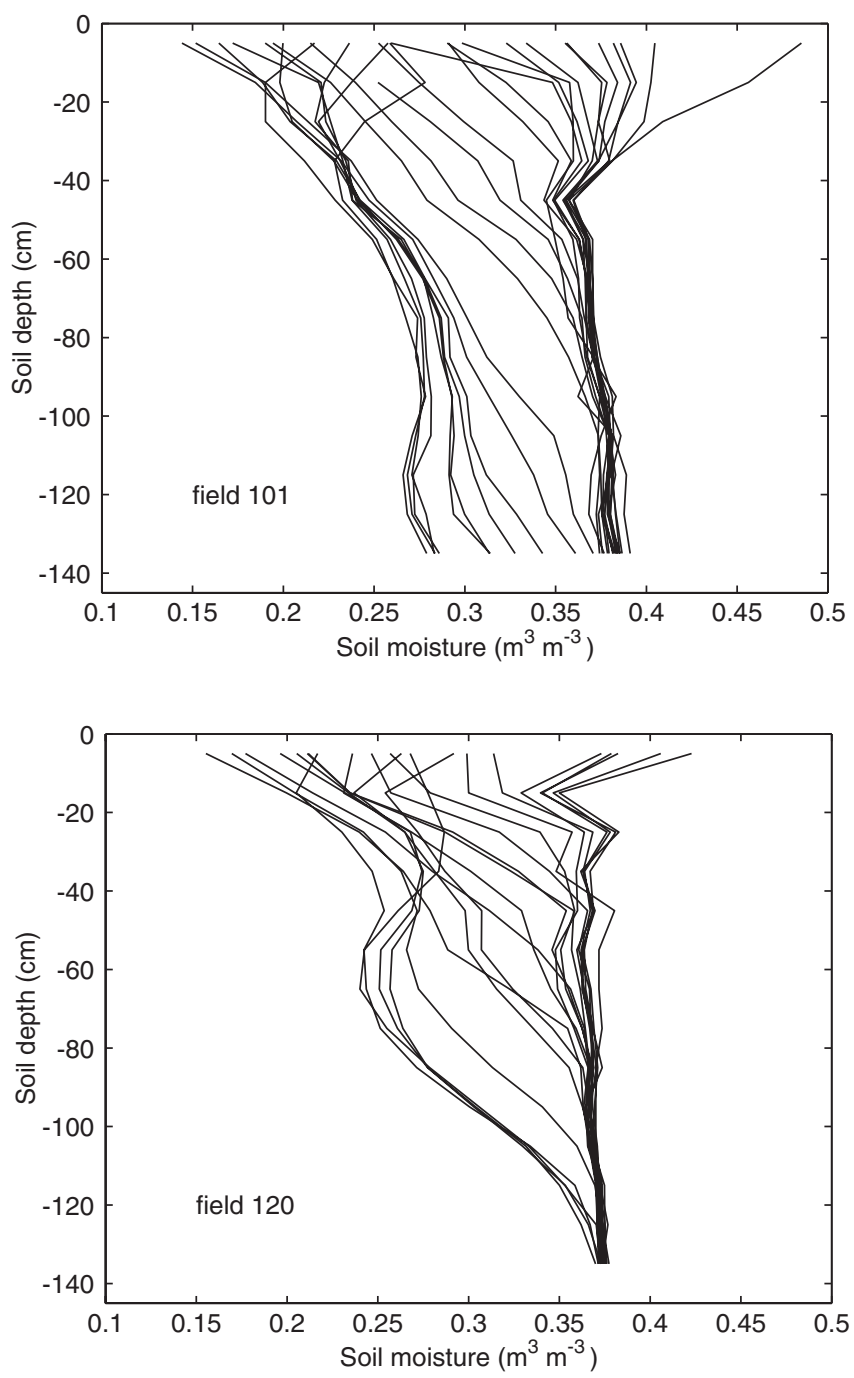

Figure 12. Soil moisture profiles for the different days of measurements in fields 101 and 120 . 


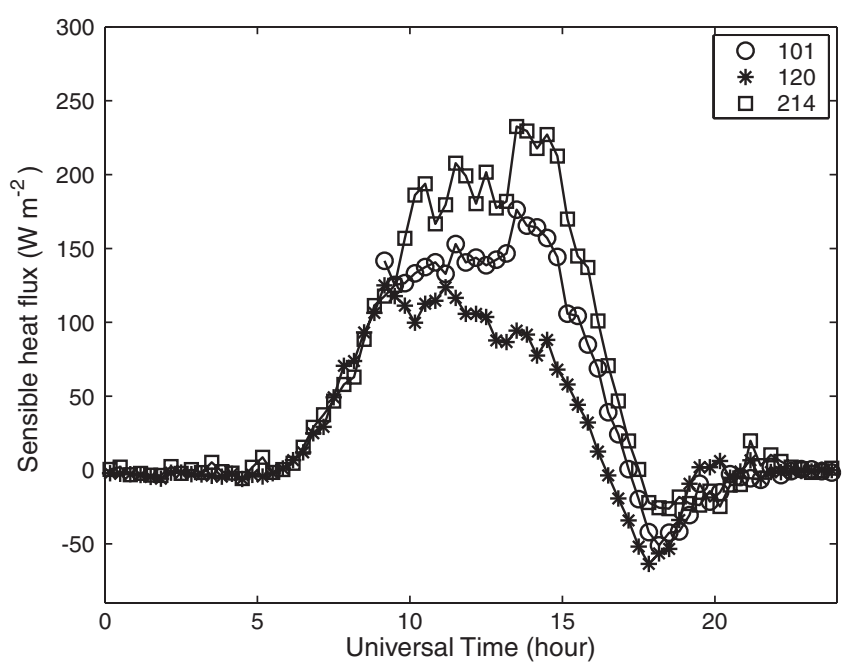

Figure 13. Comparison of sensible heat flux (eddy-correlation) for the three wheat fields on DOE 474.

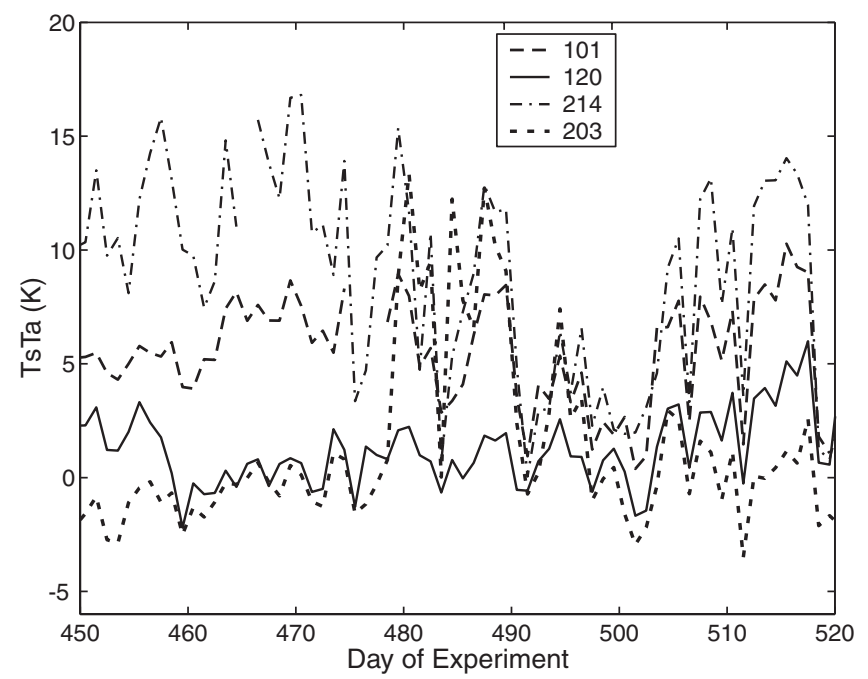

Figure 14. Comparison of the differences between surface temperature and air temperature (meteorological site) at noon on different fields (wheat: 101, 120 and 214; alfalfa: 203). The day of experiment (DOE) corresponds to the number of days since January the first, 1996.

Figure 12 gives the evolution of soil moisture profiles in fields 101 and 120, showing that water uptake occurred in the deepest measured layer $(130-140 \mathrm{~cm})$ in field 101 but not in field 120 . As soil hydraulic conductivities were very low, we think that this behavior may be closely related to the root growth; in field 120, the roots reached a depth of about $140 \mathrm{~cm}$, while they went deeper in field 101 (this was confirmed by the direct root density measurements on field 101: roots were found down to $160 \mathrm{~cm}$ at least). Roots also went deeper than $140 \mathrm{~cm}$ in field 102, and reached this depth in fields 214, 121 and 501. In field 203, as the alfalfa crop was established for more than two years, we expected that roots reached several meters deep.

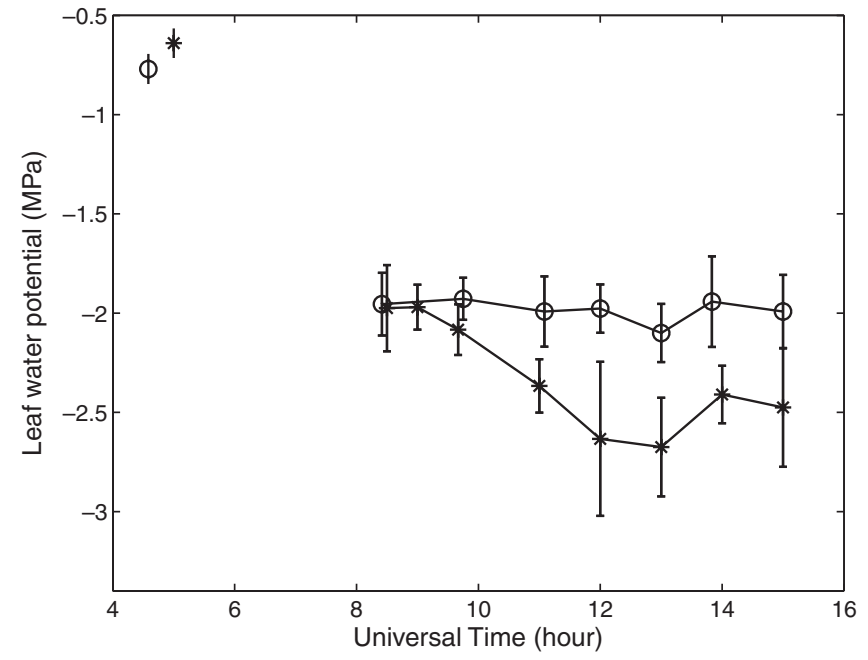

Figure 15. Leaf water potential evolution in wheat fields $101\left(^{*}\right)$ and 120 (o): average value and standard deviation on DOE 472.

Other aspects of the different behavior of the irrigated wheat field (120) and the other wheat fields are presented in Figures 13, 14 and 15: lower sensible heat flux, higher leaf water potential and lower surface temperature. In fact, for sensible heat flux, at the same time as the water status, it is necessary to consider the amount of vegetation, which was less in fields 101 and 214. In Figure 14, the effect of irrigation on field 120 is expressed by the decrease in surface temperature compared with the other fields, starting on day 457. Other features may be noticed: the temperature for alfalfa (203) was usually low, even when wilting point was reached; actually, the alfalfa rooting system usually goes deep in the soil, down to several meters, allowing a large uptake of water. However, a sharp increase in surface temperature (around $8 \mathrm{~K}$ ) occurred on DOE 479. This was due to the harvest of the above-ground material for forage, drastically reducing the canopy cover (see Fig. 10). After that, the temperature decreased while the vegetation amount increased. The surface temperature reached the same level as in field 120 about 20 days later. It is also possible to notice the effect of some rainfalls which occurred on DOE 475 (8 $\mathrm{mm}), 483(12 \mathrm{~mm})$, $491(18 \mathrm{~mm}), 492$ (7 mm), 498 (7mm) and 518 (15 mm). After the strongest rain event on DOE 491-492, the difference in temperature between the fields remained low for several days.

\section{CONCLUSION}

The Alpilles-ReSeDA experiment provided a large ground data set over a small agricultural area in the Mediterranean climate. Most aspects of energy and mass exchanges between soil, plants and the atmosphere were documented. This data set may be used for testing crop and SVAT models (see the articles by Prévot et al. [35], Moulin et al. [24] and 
Demarty et al. [14]). In particular, it will be the framework of an intercomparison experiment of several SVAT models as presented by Olioso et al. [30]. It must be noticed that crop behaviors were affected by the dry conditions imposed by the climate that year in the South-East of France. Another specificity of the data set relies on relatively homogeneous soil conditions.

The Alpilles-ReSeDA data set also includes a large amount of remote sensing data, either from airborne platforms (POLDER, INFRAMETRICS IRT camera and ERASME) or from satellites (SPOT-HRV, ERS, RADARSAT and NOAA-AVHRR). The ground data set will be used for assessing the possibility of extracting surface variables from these data and for driving SVAT or crop models. As examples, various work is currently in progress: estimation of surface soil moisture from backscattering coefficients (Chanzy et al. [10]), albedo and LAI from POLDER data (e.g. in this issue, see the articles by Jacob et al. [20] and Weiss et al. [40], as well as Jacob et al. [18]), crop development from backscattering data (Wigneron et al. [42] and Prévot et al. [34]), energy fluxes from IRT and POLDER data (e.g. in this issue, see the papers by Jacob et al. [19] and Lagouarde et al. [21], or Olioso and Jacob [29]), driving crop and SVAT models (see the articles by Prévot et al. [35] and Moulin et al. [24]), and testing hydro-meteorological modeling (Ottlé et al. [32]). Another aspect of the data set aimed to study the spatial aspect, such as the use of mixed-pixel, the aggregation of energy flux or the spatial distribution of atmospheric variables (Olioso et al. [27], Lagouarde et al. [21, 22], Courault et al. [13] and Hobbs et al. [17]).

Acknowledgments: The Alpilles-ReSeDA project was funded by the EEC-DG XII (contract ENV4-CT96-0326 - PL952071), the French Programme National de Télédétection Spatiale and Programme de Recherches en Hydrologie. The IRSA-MARS project provided access to ground data and SPOT images (Arles segment). The ESA/ESRIN provided ERS images (pilot project AO2F.115). The Laboratoire d'Optique Atmosphérique (Lille, France) provided the POLDER airborne instrument. The DAIS flight was supported by the DAIS-Large Scale Facility program. MAIS flights were supported by the Chinese Academy of Science. The flights of the IROE radiometer aboard the ARAT airplane were founded by the STAAARTE program. CIMEL Électronique provided four thermal radiometers. Further analysis of the data was done with the financial support of the EC in the framework of the WATERMED project (contract ICA3-CT-1999-00015). We must also thank Ms. Billat and MM. Bérard, de Cormis, Fabre, Grangier, Marcel and Pelouzet for letting us "wander" on their land.

\section{REFERENCES}

[1] Bertuzzi P., Bruckler L., Gabilly Y., Gaudu J.-C., Calibration and error analysis of gamma-ray probe for the in-situ measurement of dry bulk density, Soil Sci. 144 (1987) 425-436.

[2] Bertuzzi P., Chanzy A., Gaudu J.-C., Mohrath D., Acquisition et traitement de données, Document interne, INRA laboratoire de Science du Sol d'Avignon, 1997, 96 p.
[3] Braud I., Analysis of simplified infiltration tests and retrieval of soil hydrodynamic properties in the context of the Alpilles 1997 experiment, Note LTHE Grenoble, 1998, 30 p.

[4] Braud I., Chanzy A., Soil properties, initial and boundary conditions for use within SVAT models in the framework of the Alpilles-ReSeDA intercomparison, Note Alpilles 13 July 2000 (http: //avignon.inra.fr/reseda) LTHE, Grenoble, INRA-CSE, Avignon, 2000, 43 p.

[5] Burke E., Gurney R., Simmonds L., O’Neill P., Using a modeling approach to predict soil hydraulic properties from passive microwave measurements, IEEE Trans. Geosci. Remote Sens. 36 (1998) 454-462.

[6] Calvet J.-C., Noilhan J., Bessemoulin P., Retrieving the root-zone soil moisture from surface soil moisture or temperature estimates: a feasibility study based on field measurements, J. Appl. Meteorol. 37 (1998) 371-386.

[7] Camillo P., Using one- and two-layer models for evaporation estimation with remotely sensed data, in: Schmugge T., André J.C. (Eds.), Land Surface Evaporation. Measurement and Parameterization, SpringerVerlag, New York, 1991, pp. 183-197.

[8] Cellier P., Olioso A., A simple system for automated long-term Bowen ratio measurement, Agric. For. Meteorol. 66 (1993) 81-92.

[9] Chanzy A., Chadœuf J., Gaudu J.-C., Mohrath D., Richard G., Bruckler L., Monitoring soil moisture at the field scale using automatic capacitance probes, Eur. J. Soil Sci. 49 (1998) 637-648.

[10] Chanzy A., King C., Prévot L., Rémond A., Wigneron J.-P., Calcagno P., Mehrez Z., Desprats J.F., Comparison of ERS and multi-angle Radarsat measurements on bare soils: first results, in: ESA SP (FRA), 2. International Workshop on retrieval of bio- and geo-physical parameters from SAR data for land applications, Noordwijk (NLD), 1998/10/21-23 No. 441, 1998, pp. 471-477.

[11] Clapp R., Hornberger G., Empirical equations for some hydraulic properties, Water Resour. Res. 14 (1978) 601- 604.

[12] Coll C., Caselles V., Rubio E., Valor E., Sospedra F., Baret F., Prévot L., Jacob F., Temperature and emissivity extracted from airborne multi-channel data in the ReSeDA experiment, Agronomie 22 (2002) $567-573$.

[13] Courault D., Lacarrère P., Clastre P., Lecharpentier P., Jacob F., Estimation of surface fluxes using remote sensing data and the MESONH model on the ALPILLES area, in: Remote sensing and Hydrology 2001, Proceedings of a symposium held at Montpellier, France, October 2001, submitted.

[14] Demarty J., Ottlé C., François C., Braud I., Frangi J.-P., Effect of aerodynamc resistance modeling on SISPAT-RS simulated surfaces fluxes, Agronomie 22 (2002) 641-650.

[15] François C., Ottlé C., Olioso A., Prévot L., Bruguier N., Ducros Y., Conversion of 400-1100 nm vegetation albedo measurements into total shortwave broadband albedo using a canopy radiative transfer model, Agronomie 22 (2002) 611-618.

[16] Gaudu J., Mathieu J., Fumanal J., Bruckler L., Chanzy A., Bertuzzi P., Stengel P., Guennelon R., Mesure de l'humidité des sols par une méthode capacitive : analyse des facteurs influençant la mesure, Agronomie 13 (1993) 57-73.

[17] Hobbs S., Dyer D., Courault D., Olioso A., Lagouarde J.-P., Kerr Y., McAneney J., Bonnefond J.-M., Surface layer profiles of air temperature and humidity measured from unmanned aircraft, Agronomie 22 (2002) 635-640.

[18] Jacob F., Olioso A., Weiss M., Baret F., Hautecœur O., Mapping short-wave albedo of agricultural surfaces using airborne PolDER data, Remote Sens. Environ. 80 (2002) 36-46.

[19] Jacob F., Olioso A., Gu X.-F., Su Z., Seguin B., Mapping surface fluxes using airborne visible, near infrared, thermal infrared remote sensing data and a spatialized surface energy balance model, Agronomie 22 (2002) 669-680.

[20] Jacob F., Weiss M., Olioso A., French A., Assessing the narrowband to broadband conversion to estimate visible, near infrared and shortwave apparent albedo from airborne PolDER data, Agronomie 22 (2002) $537-546$. 
[21] Lagouarde J.-P., Jacob F., Gu X.-F., Olioso A., Bonnefond J.-M., Kerr Y., McAneney K.J., Irvine M., Spatialization of sensible heat flux over a heterogeneous landscape, Agronomie 22 (2002) 627-633.

[22] Lagouarde J.-P., Bonnefond J.-M., Kerr Y.H., McAneney K.J., Irvine M., Integrated Sensible Heat Flux Measurements of a Two-Surface Composite Landscape using Scintillometry, Bound.-Layer Meteorol. 105 (2002) 5-35.

[23] Laurent J.-P., Evaluation des paramètres thermiques d'un milieu poreux : optimisation d'outils de mesure "in situ", Int. J. Heat Mass Transf. 32 (1989) 1247-1259.

[24] Moulin S., Kergoat L., Cayrol P., Dedieu G., Prévot L., Calibration of a coupled canopy functioning and SVAT model in the ReSeDA experiment. Towards the assimilation of SPOT/HRV observations into the model, Agronomie 22 (2002) 681-686.

[25] Noilhan J., Jullien J., Lacarrère P., Phulpin T., Stoll M., Quelques exemples d'utilisation des données satellitaires pour la modélisation atmosphérique à moyenne échelle, in: Proceedings of the 5th International Colloquium on Physical Measurements and Signatures in Remote Sensing, INRA-CNES-CNRS-ESA, ESA SP-319, Courchevel, France, 1991, pp. 541-546.

[26] Ohmura A., Objective criteria for rejecting data for Bowen ratio flux calculations, J. Appl. Meteorol. 21 (1982) 595-598.

[27] Olioso A., Prévot L., Baret F., Chanzy A., Autret H., Baudin F., Bessemoulin P., Béthenod O., Blavoux B., Bonnefond J.M., Boubkraoui S., Bouman B.A.M., Braud I., Bruguier N., Calvet J.C., Casselles V., Chauki H., Clevers J.P.G.W., Coll C., Company A., Courault D., Dedieu G., Degenne P., Delécolle R., Spatial aspects in the Alpilles-ReSeDA project, in: Marceau D. (Ed.), Scaling and Modelling in Forestry: Application in Remote Sensing and GIS, Université de Montréal (Québec), Mars 1998, 1998, pp. 93-102.

[28] Olioso A., Chauki H., Courault D., Wigneron J.-P., Estimation of evapotranspiration and photosynthesis by assimilation of remote sensing data into SVAT models, Remote Sens. Environ. 68 (1999) 341-356.

[29] Olioso A., Jacob F., Estimation de l'évapotranspiration à partir de mesures de télédétection, La Houille Blanche 1 (2002) 62-67.

[30] Olioso, et al., SVAT modeling over the Alpilles-ReSeDA experiment: comparing SVAT models over wheat fields, Agronomie 22 (2002) 651-668.

[31] Ottlé C., Vidal-Madjar D., Assimilation of soil moisture inferred from infrared remote sensing in a hydrological model over the HAPEX-MOBILHY region, J. Hydrol. 158 (1994) 241-264.
[32] Ottlé C., Richard D., LeHegarat S., Guerin C., Noilhan J., LeMoigne P., Habets F., Modélisation hydrométéorologique du bassin du Rhône: apport de la télédétection spatiale, La Houille Blanche 1 (2002) 57-61.

[33] Prévot L., Baret F., Chanzy A., Olioso A., Wigneron J.P., Autret H., Baudin F., Bessemoulin P., Béthenod O., Blamont D., Blavoux B., Bonnefond J.M., Boubkraoui S., Bouman B.A.M., Braud I., Bruguier N., Clavet J.C., Caselles V., Chauli H., Clevers J.P.G.W., Coll C., Company A., Courault D., Dedieu G., Degenne P., Assimilation of multi-sensor and multi-temporal remote sensing data to monitor vegetation and soil: the Alpilles-ReSeDA project, in: IGARSS'98, CDRom, paper E04-03, or Vol. 5, pp. 2399-2401, IEEE, Seattle, WA, USA, 1998.

[34] Prévot L., Wigneron J.-P., Chanzy A., Baghdadi N., King C., Dechambre M., Monitoring the development of wheat crops from radar observations during the ReSeDA experiment, Agronomie (2002) submitted.

[35] Prévot L., Chauki H., Troufleau D., Weiss M., Baret F., Brisson, N., Assimilating optical and radar data into the STICS crop model for wheat, Agronomie (2002) submitted.

[36] Sellers P., Los S., Tucker C., Justice C., Dazlich D., Collatz G., Randall D., A revised land-surface parameterisation (SiB2) for atmospheric GCMs. Part 2: the generation of global fields of terrestrial biophysical parameters from satellite data, J. Clim. 9 (1996) 706-737.

[37] Soer G., Estimation of regional evapotranspiration and soil moisture conditions using remotely sensed crop surface temperature, Remote Sens. Environ. 9 (1980) 27-45.

[38] Taconet O., Bernard R., Vidal-Madjar D., Evapotranspiration over an agricultural region using a surface flux/temperature model based on NOAA-AVHRR data, J. Clim. Appl. Meteorol. 25 (1986) 284-307.

[39] Tamari S., Bruckler L., Halbertsma J., Chadœuf J., A simple method for determining soil hydraulic properties in the laboratory, Soil Sci. Soc. Am. J. 57 (1993) 642-651.

[40] Weiss M., Baret F., Leroy M., Hautecœur O., Bacour C., Prévot L., Bruguier N., Validation of neural net techniques to estimate canopy biophysical variables from remote sensing data, Agronomie 22 (2002) 547-553.

[41] Wigneron J.-P., Olioso A., Calvet J.-C., Bertuzzi P., Estimating root zone soil moisture from surface soil moisture data and soil-vegetation-atmosphere transfer modeling, Water Resour. Res. 35 (1999) 3735-3745.

[42] Wigneron J.-P., Fouilhoux M., Prévot L., Chanzy A., Olioso A., Baghdadi N., King C., Monitoring sunflower crop development from C-band radar observations, Agronomie 22 (2002) 587-595. 